\title{
Angiotensinogen (AGT) M235T, AGT T174M and Angiotensin-1- Converting Enzyme (ACE) I/D Gene Polymorphisms in Essential Hypertension: Effects on Ramipril Efficacy
}

\author{
Vana Kolovou $^{1,2}$, Evangelia Lagou ${ }^{2}$, Constantinos Mihas ${ }^{3}$, Vasiliki Giannakopoulou ${ }^{4}$, Niki Katsiki ${ }^{5}$, \\ Aikaterini Kollia $^{6}$, Filippos Triposkiadis ${ }^{7}$, Dimitris Degiannis ${ }^{2}$, Sophie Mavrogeni ${ }^{1}$ and Genovefa \\ Kolovou $^{1, *}$
}

\author{
${ }^{I}$ Cardiology Department, ${ }^{2}$ Molecular Immunology Laboratory, Onassis Cardiac Surgery Center Athens, Greece \\ ${ }^{3}$ Internal Medicine Department, General Hospital of Kimi, Evia Island, Greece \\ ${ }^{4}$ Cardiology Department, Thriassio Hospital, Magoula, Greece \\ ${ }^{5}$ Second Propedeutic Department of Internal Medicine, Medical School, Aristotle University of Thessaloniki, \\ Hippocration Hospital, Thessaloniki, Greece \\ ${ }^{6}$ Orthopedic and Urologic Departments, Veterans Administration Hospital (NIMTS), Athens, Greece \\ ${ }^{7}$ Department of Cardiology, Larissa University Hospital, Larissa, Greece
}

\begin{abstract}
Background: Hypertension, one of the most important risk factors for premature cardiovascular disease, is a major worldwide public health problem. Angiotensin-1-converting enzyme $(A C E)$ and angiotensinogen $(A G T)$ gene polymorphisms are thought to be associated with primary hypertension. In the present study, we examined the frequency of these gene polymorphisms in an adult population with and without essential hypertension. Furthermore, we evaluated the effect of $A C E$ and $A G T$ gene polymorphisms on ramipril treatment efficacy in the hypertensive patients.

Methods: A total of 166 adults (83 hypertensives and 83 normotensives) were involved in the study and genotyped for AGTM235T (rs699), AGTT174M (rs4762) and ACEI/D (rs1799752) gene polymorphisms.

Results: The genotype and allele distribution of the AGTM235T variant significantly differed between hypertensives and normotensives [odds ratio $(\mathrm{OR})=1.57 \%$ ( $\mathrm{T}$ vs $\mathrm{M}$ allele), $95 \%$ confidence intervals $(\mathrm{CIs})$ : $1.01-2.44 ; \mathrm{p}=0.045$ for hypertensives]. However, none of the 3 studied Simple Nucleotide Polymorphisms were associated with the blood pressure-lowering response to ramipril.
\end{abstract}

Conclusion: These results suggest that $A G T M 235 T$ gene polymorphism is associated with essential hypertension. However, none of the AGTM235T, AGTT174M and ACEI/D gene polymorphisms influenced ramipril effectiveness.

Keywords: $A G T M 235 T$, AGTT174, ACEI/D gene polymorphisms, efficacy, hypertension, ramipril.

\section{INTRODUCTION}

Despite numerous antihypertensive agents, hypertension is still not adequately controlled [1-3]. This can be attributed to a combination of psychosocial, socio-economic, environmental and physician-related effects, but also to a genetic predisposition. The genetic influence of blood pressure (BP) variation is expected to be approximately 30 $40 \%[4,5]$. Until now, more than 150 candidate genes have been associated with BP regulation. In this context, genes such as angiotensinogen $(A G T)$ and angiotensin-1-converting

*Address correspondence to this author at the Onassis Cardiac Surgery Center, 356 Sygrou Ave 17674 Athens, Greece; Tel: +30 210 9493520; Fax: +30 210 9493336; E-mail: genovefa@kolovou.com enzyme $(A C E)$, which encode proteins of the reninangiotensin system (RAS) have been widely evaluated $[6,7]$.

AGT is the natural substrate of RAS produced in the liver. The associations of these variants are contradictory in different populations [8]. The $A G T$ gene is located at lq42-43 and consists of 5 exons and 4 introns spanning $13 \mathrm{~kb}$ [9]. The $A G T$ gene is a logical candidate for BP control, taking into consideration the strong correlation between plasma AGT levels and BP [10]. Although several polymorphisms in the $A G T$ region have been recognized [11], a special focus has been focused on 2 polymorphisms, M235T (rs699) and T174M (rs4762), both found in exon 2.

ACE is a key zinc metallo-enzyme of the RAS widely allocated in the kidney [12]. ACE catalyzes the conversion 


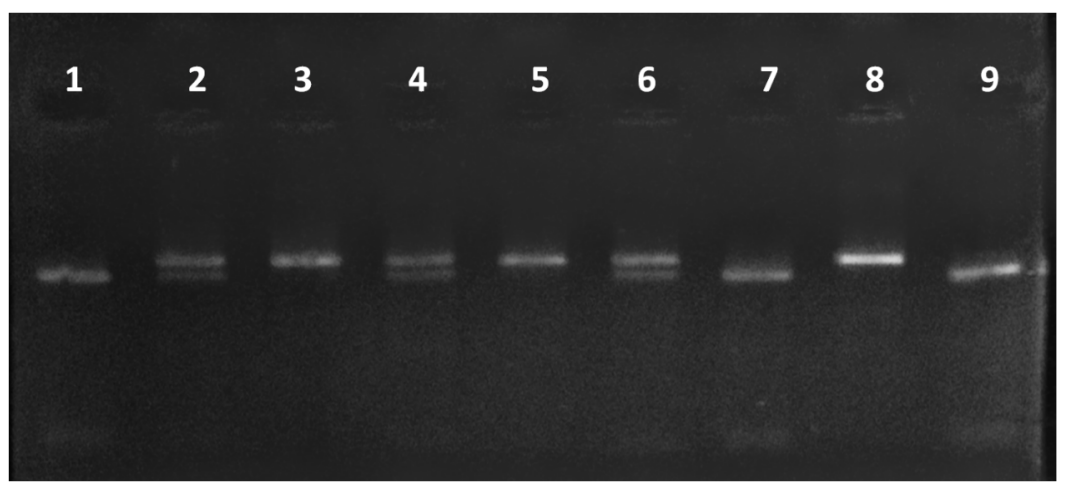

Fig. (1). AGTM235T gene polymorphism. 1, 7, 9: TT genotype; 2, 4, 6: MT genotype; 3, 5, 6: MM genotype

Abbreviations: AGT: Angiotensinogen.

of angiotensin $\mathrm{I}$ to the biologically active peptide, angiotensin II, which is involved in the control of fluid electrolyte balance and systemic BP [12]. This polymorphism is characterized by the presence (insertion) or absence (deletion) of a $287 \mathrm{bp}$ AluYa5 element inside intron 16. ACEI/D gene polymorphism has been associated with the presence of essential hypertension $[13,14]$.

Several antihypertensive drugs target RAS pathways such as ramipril, an ACE inhibitor, involved in the treatment of hypertension and congestive heart failure. In the present study, we evaluated the frequency of 3 Simple Nucleotide Polymorphisms (SNPs) such as AGTM235T (rs699), $A G T T 174 M \quad(r s 4762)$ and $A C E I / D$ (rs 1799752) in hypertensive and normotensive individuals as well as the possible influence of these Single Nucleotide Polymorphisms (SNPs) on ramipril-induced BP lowering.

\section{PATIENTS AND METHODOLOGY}

The present study was designed and performed in agreement with the recommendations for the human genotype-phenotype association studies published by the NCI-NHGRI (National Cancer Institute-National Human Genome Research Institute) Working Group on Replication in Association Studies [15] indicated time period and location of subject recruitment, success rate for DNA acquisition, internal control samples (from the same DNA) and sample tracking methods.

Subjects: A total of 166 participants were included in the present study divided into 2 groups. Control group $(n=83,56$ \pm 20 years, 44 men): subjects were recruited from the outpatient clinics of the Orthopedic and Urologic Departments of the Veterans Administration Hospital (NIMTS). Inclusion criteria were: age $18-<80$ years, no history of coronary artery disease, diabetes mellitus, thyroid and liver disease, heart and renal failure, high alcohol consumption, professional athleticism and any chronic disease, hypertension or antihypertensive drug therapy and BP within normal limits according to current guidelines $[16,17]$.

Hypertensive group ( $\mathrm{n}=83,67 \pm 13$ years, 48 men): newly-diagnosed hypertensive patients were randomly recruited from the Outpatient Clinic of the Onassis Cardiac Surgery Centre. Inclusion criteria were age $18-<80$ years, no history of thyroid and liver disease, heart and renal failure, high alcohol consumption, and elevated BP (hypertension was defined as systolic $\mathrm{BP}>140 \mathrm{mmHg}$ and/or diastolic BP $>90 \mathrm{mmHg}$ ). These patients had no prior or current use of antihypertensive agents. BP was measured twice and the lower value was recorded. The measurement was performed on the right upper arm by auscultation method after the subject had been seated for at least $5 \mathrm{~min}$. Mercury sphygmomanometers were used and the appropriate adult cuff size was applied. Secondary hypertension was excluded by the use of a detailed health questionnaire.

Written consent was obtained from each participant. The study protocol was approved by the institutional ethics committee (Onassis Cardiac Surgery Center, Athens, Greece) and was in accordance with the Declaration of Helsinki for Human Research of 1974 (last modified in 2000). All study cohorts were of Caucasian origin and descent for $\geq 3$ generations.

\section{RAMIPRIL ADMINISTRATION}

We initially administered ramipril monotherapy in the hypertensive patients (dose ranged from 2.5 to $10 \mathrm{mg}$ daily, according to BP values), followed by combination therapy (i.e. addition of a diuretic) if needed. The associations between genotypes of the 3 candidate genes and BP decrease by ramipril monotherapy were evaluated.

\section{GENOTYPING}

Genotyping was performed for research purposes. Extraction of genomic DNA was performed from leukocytes separated from whole blood using a standard method with Qiagen FlexiGene DNA kit.

The oligonucleotide primers used for AGTM235T (rs699) polymorphism were 5'-CCGTTTGTGCAGGGCCT GGCTCTC -3' and 5'-CAGGGTGTCCACACTGGCTCG -3 as described by Bennett et al. [18]. Polymerase Chain Reaction (PCR) was subjected to $95{ }^{\circ} \mathrm{C}$ for $5 \mathrm{~min}, 30$ cycles of $95^{\circ} \mathrm{C}$ for $30 \mathrm{~s}, 55^{\circ} \mathrm{C}$ for $30 \mathrm{~s}$ and $72^{\circ} \mathrm{C}$ for $30 \mathrm{~s}$ and final extension to $72^{\circ} \mathrm{C}$ for $7 \mathrm{~min}$, producing a fragment of $165 \mathrm{bp}$. This fragment was subsequently cleaved by restriction enzyme BstUI (Bacillus stearothermophilus U458), creating fragments for T allele $141 \mathrm{bp}$ and $24 \mathrm{bp}$ and for $\mathrm{M}$ allele 165 $\mathrm{bp}$, which were subjected to electrophoresis on an agarose gel $4 \%$ and visualized with ethidium bromide (Fig. 1). 


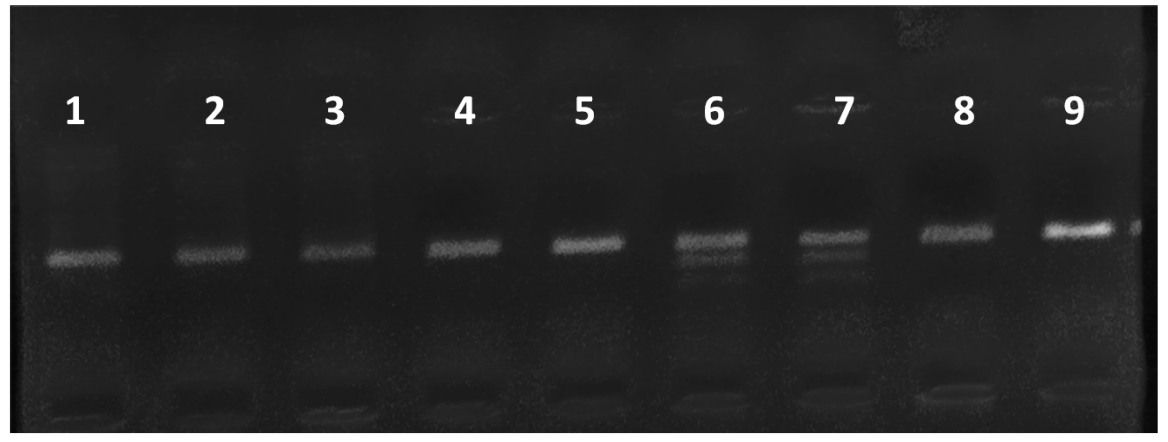

Fig. (2). AGTT174M gene polymorphism. 1-5, 8, 9: TT genotype; 6, 7: TM genotype.

MM genotype was not detected in the study groups

Abbreviations: ACE: Angiotensin-1-converting enzyme.

The oligonucleotide primers used for AGTT174M (rs4762) polymorphism were 5'-CAGGGCTGATAGCCAG GCCCA-3' and 5'-GAGAGCCAGGCCCTGCACAAA-3. PCR was subjected to $95{ }^{\circ} \mathrm{C}$ for 5 min, thirty five cycles of $95^{\circ} \mathrm{C}$ for $30 \mathrm{~s}, 64^{\circ} \mathrm{C}$ for $30 \mathrm{~s}$ and $72^{\circ} \mathrm{C}$ for $30 \mathrm{~s}$ and final extension to $72^{\circ} \mathrm{C}$ for $7 \mathrm{~min}$, producing a fragment of $103 \mathrm{bp}$. This fragment was subsequently cleaved by restriction enzyme NcoI (Nocardia coralline), creating fragments for $\mathrm{M}$ allele $70 \mathrm{bp}$ and $33 \mathrm{bp}$ and for T allele $103 \mathrm{bp}$, which were subjected to electrophoresis on an agarose gel $4 \%$ and visualized with ethidium bromide (Fig. 2).

The polymorphism $A C E I / D$ (rs1799752) within the $A C E$ gene was analyzed as previously described [6]. The PCR product is a fragment of $190 \mathrm{bp}$ when the insertion is absent and $490 \mathrm{bp}$ when the insertion is present analyzed by electrophoresis on a $4 \%$ agarose gel stained with ethidium bromide.

\section{STATISTICAL ANALYSIS}

All continuous variables are presented as mean \pm standard deviation while the categorical ones as absolute $(\mathrm{N})$ and relative (percentage) frequencies. Independent samples ttest was used to investigate for any differences of the continuous variables between the two study groups, while paired samples t-test was used in order to evaluate the differences in BP variables between baseline and after treatment. Pearson's chi-square or Fisher's exact statistic were used for testing of potential associations between categorical variables. Univariate logistic regression models were constructed in order to quantify any significant association that could derive from the simple associations. All tests were two-sided at a significance level of $\mathrm{p}<0.05$. Data were analyzed using STATA ${ }^{\mathrm{TM}}$ (Version 13.0, Stata Corporation, College Station, TX 77845, USA).

\section{RESULTS}

There were no failures in sample collection, DNA acquisition or genotyping procedures.

\section{CLINICAL AND LABORATORY PARAMETERS}

Demographic data, clinical characteristics and lipid profile of the study groups are shown in Table 1. By definition of the study protocol the prevalence of coronary artery disease, stroke and diabetes mellitus was presented in the hypertensive group only (28.9, 4.8 and $27.7 \%$, respectively). Furthermore $12 \%$ were current smokers compared with the Control group where smokers were nearly 3 times higher, $\mathrm{p}=0.001$. Age, body mass index (BMI), total cholesterol (TC), triglycerides (TGs) and low-density lipoprotein cholesterol (LDL-C) were significantly lower in the Control group compared with the hypertensive group $(\mathrm{p}=0.01$ for all comparisons).

\section{GENE FREQUENCY AND HYPERTENSION}

Genotype frequencies are shown in Table 2. The genotype and allele distribution of the AGTM235T variant significantly differed between hypertensives and normotensives [odds ratio $(\mathrm{OR})=1.57 \%$ ( $T$ vs $M$ allele), $95 \%$ confidence intervals (CIs): $1.01-2.44 ; p=0.045$ for hypertensives in the ramipril group]. Specifically, the hypertensive group had more frequently the $T T$ genotype compared with normotensive controls, $\mathrm{p}=0.042$, Table 2 . However, neither the aforementioned association nor any other cross-tabulation between genotype and allele distribution and study group were significant when tested by gender.

\section{GENE POLYMORPHISMS AND RAMIPRIL TREATMENT}

None of the 3 studied SNPs were associated with the BPlowering response to ramipril (Tables 3-5). Genotype and allele frequencies of $A G T M 235 T, A G T T 174 M$ and $A C E I / D$ gene polymorphisms were evaluated according to BPlowering response define as Grade 1 hypertension (140-159 and/or 90-99 mmHg), High normal (130-139 and/or 85-89 $\mathrm{mmHg}$ ), Normal (120-129 and/or 80-84 mmHg) and Optimal $(<120 /<80 \mathrm{mmHg})$. 
Table 1. Demographic data, clinical characteristics and lipid profile of the study groups.

\begin{tabular}{|c|c|c|c|c|c|}
\hline & & Group & & & \\
\hline & & Control & & Ramipril & \\
\hline Categorical variables & & $\mathbf{N}$ & $\%$ & $\mathbf{N}$ & $\%$ \\
\hline \multirow[t]{2}{*}{ Gender } & Men & 44 & $53.0 \%$ & 48 & $57.8 \%$ \\
\hline & Women & 39 & $47.0 \%$ & 35 & $42.2 \%$ \\
\hline \multirow[t]{2}{*}{ CAD } & Yes & 0 & $0.0 \%$ & 24 & $28.9 \%$ \\
\hline & No & 83 & $100.0 \%$ & 59 & $71.1 \%$ \\
\hline \multirow[t]{2}{*}{ Stroke } & Yes & 0 & $0.0 \%$ & 4 & $4.8 \%$ \\
\hline & No & 83 & $100.0 \%$ & 79 & $95.2 \%$ \\
\hline \multirow[t]{3}{*}{ Smoking } & Yes & 29 & $34.9 \%$ & 10 & $12.0 \%$ \\
\hline & No & 48 & $57.8 \%$ & 41 & $49.3 \%$ \\
\hline & Ex & 6 & $7.2 \%$ & 32 & $38.6 \%$ \\
\hline \multirow[t]{2}{*}{ Diabetes } & Yes & 0 & $0.0 \%$ & 23 & $27.7 \%$ \\
\hline & No & 83 & $100.0 \%$ & 60 & $72.3 \%$ \\
\hline Continuous variables & & Mean & Standard Deviation & Mean & Standard Deviation \\
\hline Age (yrs) & & 56 & 20 & 67 & 13 \\
\hline $\operatorname{BMI}\left(\mathrm{kg} / \mathrm{m}^{2}\right)$ & & 24.5 & 3.1 & 27.7 & 3.8 \\
\hline $\mathrm{TC}(\mathrm{mg} / \mathrm{dl})$ & & 170 & 31 & 231 & 60 \\
\hline $\mathrm{TG}(\mathrm{mg} / \mathrm{dl})$ & & 82 & 26 & 164 & 147 \\
\hline HDL-C (mg/dl) & & 48 & 13 & 49 & 15 \\
\hline LDL-C (mg/dl) & & 107 & 28 & 146 & 50 \\
\hline Baseline DBP (mmHg) & & 73 & 8 & 88 & 11 \\
\hline Baseline SBP (mmHg) & & 123 & 12 & 159 & 18 \\
\hline $\begin{array}{l}\mathrm{DBP}(\mathrm{mmHg}) \text { after } \\
\text { treatment }\end{array}$ & & & & 76 & 9 \\
\hline $\mathrm{SBP}(\mathrm{mmHg})$ after treatment & & & & 130 & 15 \\
\hline
\end{tabular}

Abbreviations: CAD: coronary artery disease; BMI: body mass index; TC: total cholesterol; TG: triglycerides; HDL-C: high-density lipoprotein cholesterol; LDL-C: low-density lipoprotein cholesterol, SBP: systolic blood pressure, DBP: diastolic blood pressure

Table 2. Frequency of the 3 Simple Nucleotide Polymorphisms (SNPs) in study groups.

\begin{tabular}{|c|c|c|c|c|c|c|}
\hline & & & & Group & & \\
\hline & & Control & & Ramipril & & \\
\hline & & Count & Column N \% & Count & Column N \% & $\mathbf{p}$ \\
\hline \multirow[t]{3}{*}{ AGTM235T } & MM & 30 & $36.1 \%$ & 23 & $27.7 \%$ & 0.042 \\
\hline & MT & 47 & $56.6 \%$ & 43 & $51.8 \%$ & \\
\hline & TT & 6 & $7.2 \%$ & 17 & $20.5 \%$ & \\
\hline$A G T T 174 M$ & TT & 70 & $84.3 \%$ & 65 & $78.3 \%$ & 0.319 \\
\hline
\end{tabular}




\begin{tabular}{|c|c|c|c|c|c|c|}
\hline & & & & Group & & \\
\hline & & Count & Column N \% & Count & Column N \% & $\mathbf{p}$ \\
\hline & $\mathrm{TM}$ & 13 & $15.7 \%$ & 18 & $21.7 \%$ & \\
\hline & $\mathrm{MM}$ & 0 & $0.0 \%$ & 0 & $0.0 \%$ & \\
\hline \multirow{4}{*}{$A C E I / D$} & ID & 38 & $46.3 \%$ & 43 & $51.8 \%$ & \\
\hline & $\mathrm{D}$ & 30 & $36.6 \%$ & 29 & $34.9 \%$ & \\
\hline & & & & Group & & \\
\hline & & Control & & Ramipril & & \\
\hline AGTM235 allele & $\mathrm{T}$ & 59 & $35.5 \%$ & 77 & $46.4 \%$ & \\
\hline \multirow[t]{2}{*}{ AGTT174M allele } & $\mathrm{T}$ & 153 & $92.2 \%$ & 148 & $89.2 \%$ & 0.346 \\
\hline & M & 13 & $7.8 \%$ & 18 & $10.8 \%$ & \\
\hline \multirow[t]{2}{*}{ ACEI/D allele } & I & 66 & $40.2 \%$ & 65 & $39.2 \%$ & 0.840 \\
\hline & $\mathrm{D}$ & 98 & $59.8 \%$ & 101 & $60.8 \%$ & \\
\hline
\end{tabular}

Abbreviations: AGT: Angiotensinogen; ACE: Angiotensin-1-converting enzyme.

Table 3. Frequency of $A G T M 235 T, A G T T 174 M$ and $A C E I / D$ genotype polymorphisms and level of blood pressure [grade 1 HYP (hypertension), High normal, Normal, and Optimal) defined by the European Society of Cardiology in Hypertensive group [17].

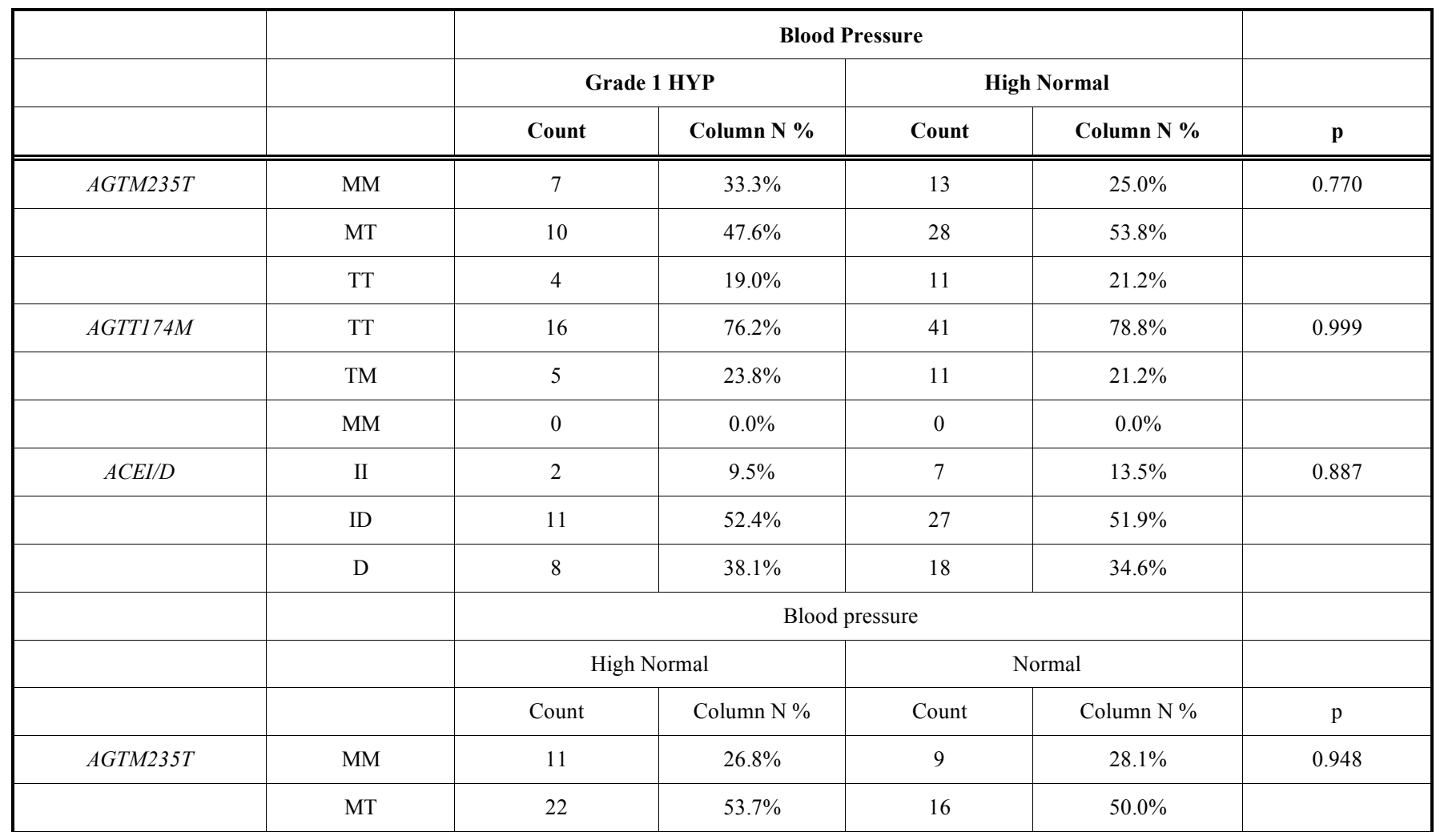


Table 3. contd...

\begin{tabular}{|c|c|c|c|c|c|c|}
\hline & & \multicolumn{4}{|c|}{ Blood Pressure } & \multirow[b]{3}{*}{$\mathbf{p}$} \\
\hline & & \multicolumn{2}{|c|}{ Grade 1 HYP } & \multicolumn{2}{|c|}{ High Normal } & \\
\hline & & Count & Column N \% & Count & Column N \% & \\
\hline & TT & 8 & $19.5 \%$ & 7 & $21.9 \%$ & \\
\hline \multirow[t]{3}{*}{$A G T T 174 M$} & TT & 31 & $75.6 \%$ & 26 & $81.3 \%$ & 0.563 \\
\hline & $\mathrm{TM}$ & 10 & $24.4 \%$ & 6 & $18.8 \%$ & \\
\hline & $\mathrm{MM}$ & 0 & $0.0 \%$ & 0 & $0.0 \%$ & \\
\hline \multirow[t]{6}{*}{$A C E I / D$} & II & 5 & $12.2 \%$ & 4 & $12.5 \%$ & 0.223 \\
\hline & ID & 18 & $43.9 \%$ & 20 & $62.5 \%$ & \\
\hline & $\mathrm{D}$ & 18 & $43.9 \%$ & 8 & $25.0 \%$ & \\
\hline & & \multicolumn{2}{|c|}{ Blood pressure } & & & \\
\hline & & \multicolumn{2}{|c|}{ Normal } & \multicolumn{2}{|c|}{ Optimal } & \\
\hline & & Count & Column N \% & Count & Column N \% & $\mathrm{p}$ \\
\hline \multirow[t]{3}{*}{$A G T M 235 T$} & MM & 17 & $28.8 \%$ & 3 & $21.4 \%$ & 0.736 \\
\hline & MT & 31 & $52.5 \%$ & 7 & $50.0 \%$ & \\
\hline & $\mathrm{TT}$ & 11 & $18.6 \%$ & 4 & $28.6 \%$ & \\
\hline \multirow[t]{3}{*}{$A G T T 174 M$} & TT & 47 & $79.7 \%$ & 10 & $71.4 \%$ & 0.721 \\
\hline & $\mathrm{TM}$ & 12 & $20.3 \%$ & 4 & $28.6 \%$ & \\
\hline & $\mathrm{MM}$ & 0 & $0.0 \%$ & 0 & $0.0 \%$ & \\
\hline \multirow[t]{3}{*}{$A C E I / D$} & II & 8 & $13.6 \%$ & 1 & $7.1 \%$ & 0.637 \\
\hline & ID & 29 & $49.2 \%$ & 9 & $64.3 \%$ & \\
\hline & $\mathrm{D}$ & 22 & $37.3 \%$ & 4 & $28.6 \%$ & \\
\hline
\end{tabular}

Grade 1 hypertension (140-159 and/or 90-99 mmHg), High normal (130-139 and/or 85-89 mmHg), Normal (120-129 and/or 80-84 mmHg) and Optimal (<120/<80 mmHg).

Abbreviations: AGT: Angiotensinogen; ACE: Angiotensin-1-converting enzyme.

Table 4. Allele Frequency of $A G T M 235 T, A G T T 174 M$ and $A C E I / D$ gene polymorphisms level of blood pressure [grade 1 HYP (hypertension), High normal, Normal, and Optimal) defined by the European Society of Cardiology in Hypertensive group [17].

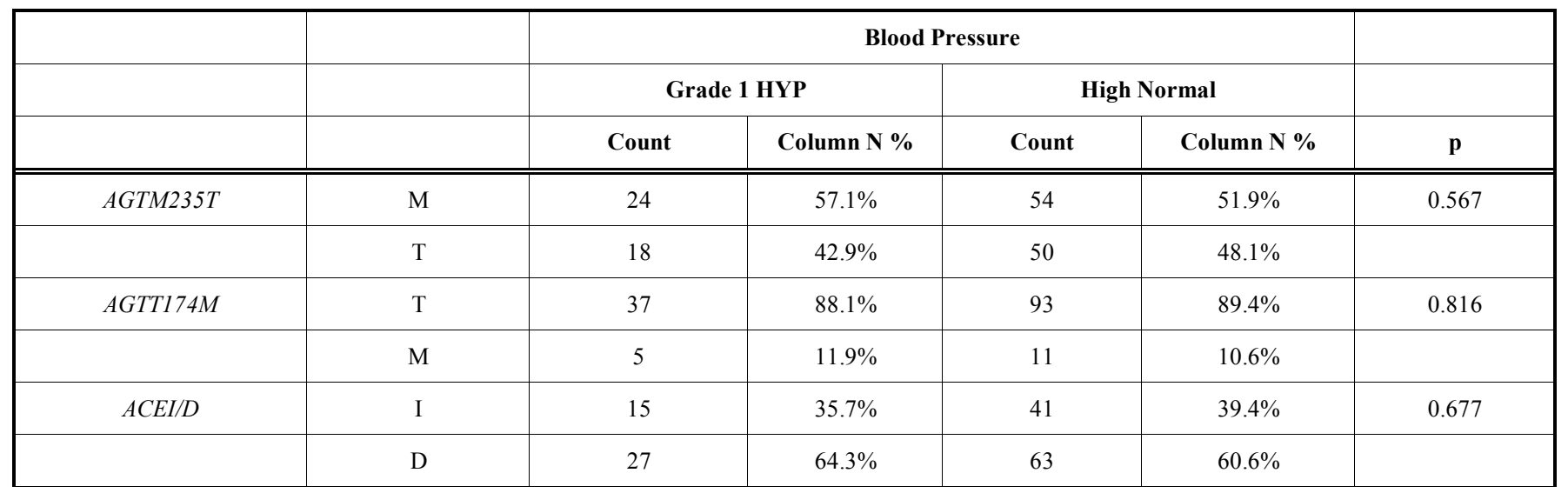




\begin{tabular}{|c|c|c|c|c|c|c|}
\hline & & \multicolumn{4}{|c|}{ Blood Pressure } & \\
\hline & & Count & Column N \% & Count & Column N \% & \\
\hline \multirow[t]{2}{*}{ AGTM235T } & M & 44 & $53.7 \%$ & 34 & $53.1 \%$ & 0.949 \\
\hline & $\mathrm{T}$ & 38 & $46.3 \%$ & 30 & $46.9 \%$ & \\
\hline AGTT174M & M & 10 & $12.2 \%$ & 6 & $9.4 \%$ & \\
\hline \multirow[t]{3}{*}{$A C E I / D$} & I & 28 & $34.1 \%$ & 28 & $43.8 \%$ & 0.236 \\
\hline & $\mathrm{D}$ & 54 & $65.9 \%$ & 36 & $56.3 \%$ & \\
\hline & & \multicolumn{4}{|c|}{ Blood pressure (optimal) } & \\
\hline \multirow[t]{2}{*}{$A G T M 235 T$} & M & 65 & $55.1 \%$ & 13 & $46.4 \%$ & 0.409 \\
\hline & $\mathrm{T}$ & 53 & $44.9 \%$ & 15 & $53.6 \%$ & \\
\hline \multirow[t]{2}{*}{ AGTT174M } & $\mathrm{T}$ & 106 & $89.8 \%$ & 24 & $85.7 \%$ & 0.738 \\
\hline & M & 12 & $10.2 \%$ & 4 & $14.3 \%$ & \\
\hline \multirow[t]{2}{*}{$A C E I / D$} & I & 45 & $38.1 \%$ & 11 & $39.3 \%$ & 0.910 \\
\hline & $\mathrm{D}$ & 73 & $61.9 \%$ & 17 & $60.7 \%$ & \\
\hline
\end{tabular}

Grade 1 hypertension (140-159 and/or 90-99 mmHg), High normal (130-139 and/or 85-89 mmHg), Normal (120-129 and/or 80-84 mmHg) and Optimal (<120/<80 mmHg). Abbreviations: AGT: Angiotensinogen; ACE: Angiotensin-1-converting enzyme

Tables 5. Genotype and alleles in association with blood pressure differences changes.

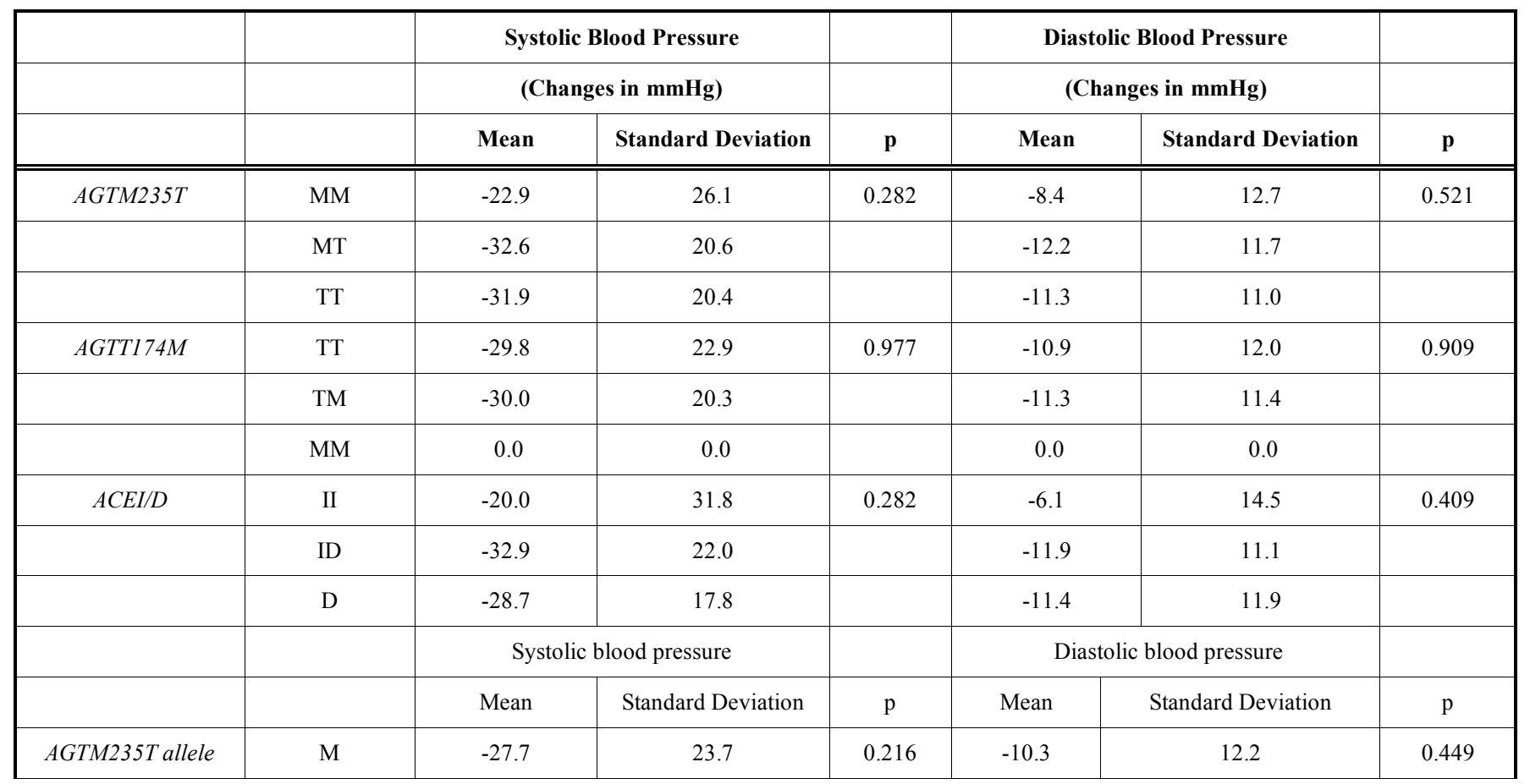


Table 5. contd...

\begin{tabular}{|c|c|c|c|c|c|c|c|}
\hline & & \multicolumn{2}{|c|}{ Systolic blood Pressure } & & \multicolumn{2}{|c|}{ Diastolic Blood Pressure } \\
\hline & & Mean & Standard Deviation & $\mathbf{p}$ & Mean & Standard Deviation & $\mathbf{p}$ \\
\hline \hline & $\mathrm{T}$ & -32.3 & 20.2 & & -11.8 & 11.2 \\
\hline AGTT174M allele & $\mathrm{T}$ & -29.8 & 22.4 & 0.979 & -11.0 & 11.8 & 0.915 \\
\hline & $\mathrm{M}$ & -30.0 & 20.3 & & -11.3 & 11.4 \\
\hline ACEI/D allele & $\mathrm{I}$ & -28.8 & 25.6 & 0.637 & -10.1 & 12.3 \\
\hline
\end{tabular}

Abbreviations: AGT: Angiotensinogen; ACE: Angiotensin-1-converting enzyme.

\section{DISCUSSION}

As there is a genetic predisposition to hypertension and elevated BP is inadequately controlled, several candidate genes have been investigated with regard to BP regulation. $A G T$ and $A C E$ genes that affect the RAS have been widely evaluated $[6,7]$. In the present study, we evaluated 3 SNPs in 2 candidate genes involved in RAS-related pathways, also investigating their potential impact on ramipril monotherapy efficacy. We found that AGTM253T (rs699) gene polymorphism frequency is different between hypertensives and controls. No differences in the frequency of AGTT174M (rs4762) and ACEI/D (rs 1799752) gene polymorphisms between the 2 study groups were observed. Furthermore, none of these 3 SNPs was shown to affect the BP-lowering effects of ramipril monotherapy.

Jeunemaitre et al. [9] originally explored the potential role of $A G T$ gene in hypertension through a linkage study. Two different meta-analyses in Chinese populations confirmed that the $T$ allele of $A G T M 235 T$ polymorphism is associated with essential hypertension $[19,20]$. However, Niu et al found no association of essential hypertension with $A G T M 235 T$ or AGTT174M polymorphisms, even after stratification by age, gender or disease severity [21]. Similarly, Caulfield et al. [22] did not report any association with either AGTM235T or AGTT174M gene polymorphisms. Mohana et al. [23] reported an increase in the risk for hypertension in women only with the AGTM235T polymorphism $(\mathrm{OR}=2.82 ; 95 \% \mathrm{CI}=1.22-6.49 ; \mathrm{p}=0.012)$. Therefore, some studies confirm the association $[11,24]$ and others refute it [25-27]. In our study, the hypertensive group had approximately 3 times more frequently the $T T$ genotype of the AGTM235T gene polymorphism compared with normotensive controls, $\mathrm{p}=0.042$.

With regard to the AGTT174M polymorphism, Mohana et al. [23] reported significant differences between hypertensives and normotensives. Also, a meta-analysis of the association of $4 A G T$ polymorphisms with essential hypertension confirmed this association [28]. Although an analysis by ancestry revealed that in Asian and mixed populations the $174 \mathrm{M}$ allele was associated with an increased risk for hypertension (OR: 1.31; 95\% CI: $1.02-1.69$; p = 0.04 and OR: $1.43 ; 95 \%$ CI: $1.11-1.83 ; \mathrm{p}=0.005$, respectively), no clear evidence for a role of this variant is observed in European ethnicity populations (OR: 1.03; 95\%
CI: $0.92-1.15 ; p=0.61)$ [25]. In our study, we did not find any differences in the frequency of this polymorphism between the 2 study groups.

With regard to $A C E I / D$ gene polymorphisms, there are studies with inconsistent results. Dhanachandra Singh Kh et al. [29] found overrepresentation of the $A C E I$ allele in normotensive males, thus suggesting its protective role. He et al. [13] also found that the $A C E I / D$ gene polymorphism plays a role in hypertension. Furthermore, meta-analyses reported that $D D$ genotype of the $A C E I / D$ polymorphism [14] were associated with essential hypertension. In the present study, we did not observe any differences in $A C E I / D$ gene polymorphism frequency between the 2 study groups. Similarly, no association was found in Chinese, Italian, Greek, Japan and Indian populations [30, 31]. Whether this disagreement is due to racial, environmental factors or the inclusion criteria used in each study is unknown and needs additional investigation.

There are only a few studies evaluating the association between AGTM235T, AGTT174M and ACEI/D gene polymorphisms with the BP-lowering effect of ramipril. Zivko et al. [32] did not find any significant impact of $A C E I / D$ gene polymorphisms on ramipril-related BPdecreasing effect in 66 hypertensive patients. Similarly, in the present study, we did not observe any significant differences in BP changes with regard to $I / D$ polymorphism. In contrast, Gupta et al. [33] reported that the percentage of responders to ramipril therapy was significantly higher in patients with the $I I$ genotype compared with those with the $I D$ genotype. As there is an inconsistency of findings across studies, the effects of these polymorphisms on ramiprilrelated BP changes still remain unclear.

With regard to the other 2 AGT SNPs (M235T and $T 174 M$ ), to our knowledge, the present study is the first to evaluate their association with ramipril efficacy, reporting no correlations. It should be noted that the main limitation of this study is the relatively small sample size.

\section{CONCLUSION}

In the present study, we found that only the frequency of AGTM235T (rs699) variant is significantly $(\mathrm{p}=0.045)$ different between hypertensives and controls. No gender differences in the frequency of AGTT174M (rs4762), 
AGTM235T (rs1799752) and ACEI/D (rs 1799752) gene polymorphisms were observed in both study groups. Furthermore, these 3 SNPs did not influence the BPlowering efficacy of ramipril. However, as this is a small study, future research on larger populations is needed to establish these associations.

\section{CONFLICT OF INTEREST}

The authors confirm that this article content has no conflict of interest.

\section{ACKNOWLEDGEMENTS}

Declared none.

\section{REFERENCES}

[1] Hertz RP, Unger AN, Cornell JA, Saunders E. Racial disparities in hypertension prevalence, awareness and management. Arch Intern Med 2005; 165: 2098-104.

[2] Natarajan S, Santa Ana EJS, Liao Y, Lipsitz SR, McGee DL. Effect of treatment and adherence on ethnic differences in blood pressure control among adults with hypertension. Ann Epidemiol 2009; 19: 172-9.

[3] Steyn K, Gaziano TA, Bradshaw D, Laubscher R, Fourie J. Hypertension in South African adults: results from the Demographic and Health Survey, 1998. J Hypertens 2001; 19: 1717-25.

[4] Weder AB. Genetics and hypertension. J Clin Hypertens 2007; 9: 217-23.

[5] Kolovou GD, Mavrogeni S. Genetics of human hypertension, the role of angiotensinogen. Should it be one of the drug target genes? Angiology 2014; 65: 269-71.

[6] Rigat B, Hubert C, Corvol P, Soubrier F. PCR detection of the insertion/deletion polymorphism of the human angiotensin converting enzyme gene (DCP1) (dipeptidyl carboxypeptidase 1). Nucleic Acids Res 1992; 20: 1433.

[7] Russ AP, Maerz W, Ruzicka V, Stein U, Gross W. Rapid detection of the hypertension-associated Met235-->Thr allele of the human angiotensinogen gene. Hum Mol Genet 1993; 2: 609-10.

[8] Pereira AC, Mota GF, Cunha RS, Herbenhoff FL, Mill JG, Krieger JE. Angiotensinogen 235T allele "dosage" is associated with blood pressure phenotypes. Hypertension 2003; 41: 25-30.

[9] Jeunemaitre X, Soubrier F, Kotelevtsev YV, et al. Molecular basis of human hypertension: role of angiotensinogen. Cell 1992; 71: 169-80.

[10] Walker WG, Whelton PK, Saito H, Russel RP, Hermann J. Relation between blood pressure and renin, renin substrate, angiotensin II, aldosterone and urinary sodium and potassium in 574 ambulatory subjects. Hypertension 1979; 1: 287-91.

[11] Jeunemaitre X, Inoue I, Williams C, et al. Haplotypes of angiotensinogen in essential hypertension. Am J Hum Genet 1997; 60: $1448-60$.

[12] Sayed-Tabatabaei FA, Oostra BA, Isaacs A, van Duijn CM, Witteman JC. ACE polymorphisms. Circ Res 2006; 98: 1123-33.

[13] $\mathrm{He} \mathrm{Q}$, Fan $\mathrm{C}, \mathrm{Yu} \mathrm{M}$, et al. Associations of ACE gene insertion/deletion polymorphism, ACE activity, and ACE mRNA expression with hypertension in a Chinese population. PLoS One 2013; 8: e75870.

[14] Li Y. Angiotensin-converting enzyme gene insertion/deletion polymorphism and essential hypertension in the Chinese population: a meta-analysis including 21,058 participants. Int Med J 2012; 42: 439-44.
[15] Chanock SJ, Manolio T, Boehnke M, et al. NCI-NHGRI Working Group on Replication in Association Studies, Replicating genotype-phenotype associations. Nature 2007; 447: 655-60.

[16] Kjeldsen S, Feldman RD, Lisheng L, et al. Updated national and international hypertension guidelines: a review of current recommendations. Drugs 2014; 74: 2033-51.

[17] Mancia G, Fagard R, Narkiewicz K, et al. 2013 ESH/ESC guidelines for the management of arterial hypertension: The task force for the management of arterial hypertension of the European Society of Hypertension (ESH) and of the European Society of Cardiology (ESC). Eur Heart J 2013; 34: 2159-219.

[18] Bennett CL, Schrader AP, Morris BJ. Cross-sectional analysis of Met235--> Thr variant of angiotensinogen gene in severe, familial hypertension. Biochem Biophys Res Commun 1993; 197: 833-9.

[19] Ji LD, Zhang LN, Shen P, et al. Association of angiotensinogen gene M235T and angiotensin-converting enzyme gene I/D polymorphisms with essential hypertension in Han Chinese population: a meta-analysis. J Hypertens 2010; 28: 419-28.

[20] Xi B, Shen Y, Yan Y, Mi J. Association of polymorphisms in the AGT gene with essential hypertension in the Chinese population. J Renin Angiotensin Aldosterone Syst 2012; 13: 282-8.

[21] Niu $\mathrm{T}$, Yang $\mathrm{J}$, Wang $\mathrm{B}$, et al. Angiotensinogen gene polymorphisms M235T/T174M: no excess transmission to hypertensive Chinese. Hypertension 1999; 33: 698-702.

[22] Caulfield M, Lavender P, Farrall M, et al. Linkage of the angiotensinogen gene to essential hyper- tension. N Engl J Med 1994; 330: 1629-33.

[23] Mohana VU, Swapna N, Surender RS, Vishnupriya S, Padma T. Gender-related association of AGT gene variants (M235T and T174M) with essential hypertension a case-control study. Clin Exp Hypertens 2012; 34: 38-44.

[24] Hata A, Namikawa C, Sasaki M, et al. Angiotensinogen as a risk factor for essential hypertension in Japan. J Clin Invest 1994; 93: 1285-7.

[25] Barley J, Blackwood A, Sagnella G, Markandu N, MacGregor G, Carter N. Angiotensinogen Met2353Thr polymorphism in a London normotensive and hypertensive black and white population. J Hum Hypertens 1994; 8: 639-40.

[26] Rotimi C, Morrison L, Cooper R, et al. Angiotensinogen gene in human hypertension: lack of an association of the T235 allele among African Americans. Hypertension 1994; 24: 591-4

[27] Fornage M, Turner ST, Sing CF, Boerwinkle E. Variation at the M235T locus of the angiotensinogen gene and essential hypertension: a population-based case-control study from Rochester, Minnesota. Hum Genet 1995; 96: 295-300.

[28] Pereira TV, Nunes AC, Rudnicki M, Yamada Y, Pereira AC, Krieger JE. Meta-analysis of the association of 4 angiotensinogen polymorphisms with essential hypertension: a role beyond M235T? Hypertension 2008; 51: 778-83.

[29] Singh KD, Jajodia A, Kaur H, Kukreti R, Karthikeyan M. Gender specific association of RAS gene polymorphism with essential hypertension: a case-control study. Biomed Res Int 2014; 2014: 538053.

[30] Ishigami $\mathrm{T}$, Iwamoto $\mathrm{T}$, Tamura $\mathrm{K}$, et al. Angiotensin I converting enzyme (ACE) gene polymorphism and essential hypertension in Japan. Ethnic difference of ACE genotype. Am J Hypertens 1995; 8: 95-7.

[31] Martinez E, Puras A, Escribano J, et al. Angiotensin- converting enzyme (ACE) gene polymorphisms, serum ACE activity and blood pressure in a Spanish Mediterranean population. J Hum Hypertens 2000: 14; 131-5.

[32] Zivko M, Kusec R, Galesić K. Impact of angiotensin-converting enzyme gene polymorphism on proteinuria and arterial hypertension. Coll Antropol 2013; 37: 765-70.

[33] Gupta S, Chattopadhyaya I, Agrawal BK, Sehajpal PK, Goel RK. Correlation of renin angiotensin system (RAS) candidate gene polymorphisms with response to Ramipril in patients with essential hypertension. J Postgrad Med 2015; 61:21-6.

This is an open access article licensed under the terms of the Creative Commons Attribution-Non-Commercial 4.0 International Public License (CC BY-NC 4.0) (https://creativecommons.org/licenses/by-nc/4.0/legalcode), which permits unrestricted, non-commercial use, distribution and reproduction in any medium, provided the work is properly cited. 